\section{Museum Reform}

No one acquainted with the condition of the greater proportion of our provincial museums can do otherwise than confess with sorrow that much of what is alleged against them in the paper of Mr. Boyd Dawkins is too true. While fully concurring in all he says as to the actual state of matters in these amorphous receptacles of curiosities and conceits, and as to the crying need for reform, you will perhaps allow me to make a few comments as to the causes which contribute to keep museum collections in their present cisreputable condition, and the means by which they may be worthily organised, and raised to their high and proper position among the educational agencles of the country.

It is necessary in the first place to accept Mr. Boyd Dawkins's glorification of the collecting instinct with some modification or rather amplification of its scope. A man is indeed "poor and much to be pitied" who is not a collector in some sense; but it does not require demonstration that many of the best and greatest benefactors of mankind are not collectors in a way that contributes to the building up of museums. Statesmen, soldiers, poets, philosophers, and orators are not of necessity poor and much to be pitied because they may not devote their leisure to the collection of coleoptera nor find solace in the beauties of Lucca della Robbia. In nine cases out of ten, indeed, the collector is a person of one idea, and that idea is that the gathering, labelling, and arranging of the objects of his fancy is the beginning, end, and sum of science. He is generally an estimable person; but as regards scientific culture he is quite as well employed in collecting spoiled postage stamps as he would be in gathering together the species of any of the rreat divisions of the animal kingdom. When we come to the tenth man-the intellectual collector-we find a really scientific worker, but one necessarily confrning himself to a limited field. He is in short a man with a hobby, or, to put it more courteously, a specialist. Put a man of this select class in charge of a provincial museum, and while probably he is too wise to speak slightingly of any department of buman knowledge, he wili inevitably develop his own special subject at the expense of all others. A geologist draws towards him rocks and fossils, an entomologist collects in the particular group of insects to which he has given attention, and an archrologist looks only or mainly for anticuitics. If the man is a simple coilector of the ordinary type he knows nothing or despises everything beyond his region, and hence in part the jumble of ethnology, art, and science which Mr. Boyd Dawkins so graphically describes.

A specialist, though an indispensable cultivator of science, is a very bad museum curator. A curator should be like a news. paper editor, a man of general knowledge and culture. Unlike an editor, he should belong to no party, but be possessed of catholic sympatibies in science and art; ready to accept and use the assistance of specialists, in a way that will subordinate all departments to one harmonious general plan. Further, he should possess an experimental knowledge of the routine dutjes of a museum, such as can only be obtained by a training or apprenticeship in a well-organised museum.

No provision, I need hardly say, exists at the present time for training young inen to museum work, ar, there is no pecuniary inducement licld out for lads to seek curatorial qualifications. The training obtained in the great metropolitan museums is special; and in the government service there is no hiving off of apprentices. Municipal and free library authorities have not yet learnt that a well-equipped nuseum is an expensive institu. tion, and though many corporation dignitaries may spendannually I, 000 l. and upwards on purchases for their private collections, it does not occur to them that it is necessary to do more than open the doors of a public nuseum or art gallery, and allow collections to accumulate, arrange, classify, catalogue, and conserve very much of their own accord. And so we obtain the dusty, misleading, higgeldy-piggeldies which do duty in provincial towns as "museums."

Before these institutions can rise from their present disma estate it is essential that much more money be devoted to them. Of course it does not matter whence the funds come-from public rates or private benefaction-provided it comes honestly; but there is, as the law now stands, hardly in any town sufficient rating power to build and maintain a museum adequate to the population and wants of the locality. Free library boards with their penny rating limit have in many instances committed themselves to very ambitious mistakes by instituting numerous district libraries, and throwing in a public museum to the bargain, under the delusion either that their penny is like the wizard's inexhaustible bottle, or that these institutions will live and flourish "without visible means of support." The result is, that while libraries have been crippled and half starved, ratepayers have been justly disgusted with the very name of museum.

The provincial public mind, both official and extra-official, stands sorely in need of enlightenment as to the nature and functions of a museum. The education of opinion on these points is the first step required for the elevation of local museums. With that effected, enlarged rating power, a demand for competent men, and adequate support to institutions on a broad educational basis would soon follow. Local museums, ceasing to be mere curiosity-shops, receptacles of "relics from Sedan," "water from the Jordan," with six-legged cats and similar monstrosities, would become storehouses of well-selected information and material for the use of teachers and investigators, as well as instructive and elevating resorts of the general public.

No class of institutions existing rould be made mutually more helpful than museums. Duplicates innumerable go to wreck and destruction in the stores and cellars of almost every museum, while certainly many kindred institutions stand in need of what is simply an encumbrance to some. Similarly with labels and stores of information, $\epsilon$ ach institution at present stands apart, working painfully, and perhaps erringly, at tasks which might well be spared, seeing that it is and has been clone over and over again in other institutions. Again, one locality possesses rare and unusual facilities for obtaining particular classes of objects, and that advantage can,iby a system of exchange, be made properly beneficial to its own museum by drawing what it needs from others. Further, in these days of comparative infancy, the experience of the officers of the older museums would be of unspeakable value to those struggling amid difficulties of which they barely recognise the nature; and to all, the countenance of the great institutions-which should be prepared to stand more in loco parentis than they at present do-and the advice and help of their specialists would be of much advantage. In these days of conferences, associations, ancl unions, it is manifest that there is room for a conference of museum keepers, and no one can doubt that vast go a wovld result from drawing the officers of museums of all kincis inte closer relationship with each other. Will the energetic officers of South Kensiugton not display crce more their organising talent by bringing together such a conference, which, it may be hoped, would result in a permanent union among museum officers.

J. P.

\section{Taunton College School}

MAy I ask the insertion of the following brief remank:-

The writer of the article in your paper of the 28 th on Taunton College School is ur der some strange misapprehension, which nerhaps may account for his unfavourable criticism of the schemes of the Endowed Schools' Commission. He clearly implies, though he does not positively state, that the presert disturbance at Tamnon (of which 1 know nothing) and the scandal at Felsted two or three years ago are in some way attributable to the wrong constitution of the governing body, under schemes of the Endowed Schools' Commission.

Taunton College School is not under a scheme of the Endowed Schools' Commission, and no scbeme was ever proposed for it by that body. A schene for Felsted Grammar Schucl was proposed by the Endowed Schools' Commission, with the hearty goodwill of the late master, but was rejected by the House of Lords on the motion of the Bishop of Rochester (now of St. Alban's). The trustees who dismissed Dr. Grignon were the very body whose constitution our scheme proposed largely to modify, and who were in consequence not a little annoyed.

Your writer will, I hope, excuse my saying that he will serve the cause of science and of schools much beiter if he does not weaken his attacks on the guilty by hitting, or making feints of bitting, at the innocent. HENRY J. RoBY,

Manchester, June 29 Commissioners

\section{Hog Wallows}

I HAVE been watching with some interest the progress of the discussion on the "Hog Wallows" of California, which has been in progress in your paper during nearly all of this year. When a mẹmber of the California Geological Survey Corps, I 